\title{
Controlled Clinical Trial of Clofazimine in Untreated Lepromatous Leprosy*
}

\author{
A. B. A. KARAT, ANBU JEEVARATNAM, S. KARAT, P. S. S. RAO
}

British Medical fournal, 1971, 4, 514-516

\begin{abstract}
Summary
A comparison of clofazimine and dapsone in the management of untreated lepromatous leprosy showed no significant differences between the two drugs in terms of morphological and bacterial indices. The incidence of erythema nodosum leprosum was similar in the two groups. Since dapsone is cheaper than clofazimine it remains the drug of choice for the routine management of untreated lepromatous leprosy.
\end{abstract}

\section{Introduction}

While sulphones brought a ray of hope in the dismal picture of leprosy following the reports from Faget et al. (1943), the initial expectations of a "miracle drug" were replaced by a factual appraisal of the therapeutic effects of sulphones. Two main findings emerged in the post-sulphone era-namely, (1) sulphones, though effective in the treatment of leprosy, need to be given over a period of years rather than months to achieve "cure" of lepromatous leprosy, and (2) with the introduction of sulphones the incidence of "reactions" increased significantly. While acknowledging the unmistakable therapeutic effects of sulphone, search for a more effective and less toxic drug with less tendency to precipitate exacerbated phases of the disease has continued through the last three decades. Clofazimine (Lamprene), a riminophenazine derivative, is one such drug which gave promise of effectiveness in the early 'sixties (Browne and Hogerzeil, 1962; Chang, 1962; Brechet, 1963; Davey, 1964; Browne, 1965; Williams et al., 1965; Pettit et al., 1967). It was suggested that while effectively killing the lepra bacillus clofazimine exerted a suppressive effect on the occurrence of exacerbated phases and hence could be used with advantage in the management of lepromatous leprosy.

We have been conducting clinical trials with clofazimine since March 1968, and a paper on its efficacy in the management of reactive phases of lepromatous leprosy has already been published (Karat et al., 1970). In this report our experiences with clofazimine at the dosage of $100 \mathrm{mg}$ once a day in the management of untreated lepromatous leprosy are reported and discussed in terms of (a) change in morphological index scored according to Shepard and McRae's (1965) method; (b) change in bacterial index, according to Ridley's (1964) scale, based on skin smears taken from eight sites; $(c)$ effect on skin lesions; $(d)$ effect on peripheral nerve functions, as judged by manual muscle tests, strength-duration curves, and sensory maps of upper and lower limbs below the elbow and below the

*Sponsored and financed by Geigy S.A., Basle, Switzerland.

Church of South India Hospital, Bangalore-1A, India

A. B. A. KARAT, B.SC., M.R.C.P.(LOND., ED.), Consultant Physician

S. KARAT, M.B., F.R.c.s.eD., Consultant Orthopaedic Surgeon

Christian Medical College and Hospital, Vellore, India

ANBU JEEVARATNAM, M.B., B.S., Senior House Physician

P. S. S. RAO, M.P.H., F.S.S., Chief, Department of Biostatistics knee respectively; $(e)$ incidence of erythema nodosum leprosum reactions while on treatment; $(f)$ changes in haematological, hepatic, and renal functions; $(g)$ improvement in general condition-for example, weight; and $(h)$ side effects.

\section{Patients and Methods}

Clofazimine $100 \mathrm{mg}$ once a day was evaluated against dapsone $100 \mathrm{mg}$ once a day. If the patient should develop a reaction (erythema nodosum leprosum of $2+$ or greater severity or acute neurological catastrophe) the specific drug was to be continued and an anti-inflammatory drug randomly allocated: aspirin $3 \mathrm{~g} /$ day; chloroquine $750 \mathrm{mg} /$ day; or prednisolone $15 \mathrm{mg}$ /day. If this failed to control the reaction the patient then entered into another trial wherein clofazimine at a higher dosage or prednisolone $30 \mathrm{mg} /$ day was given while the present therapeutic regimen continued uninterrupted.

Patients over 15 years of age with LL type of lepromatous leprosy and bacterial index more than $1+$, and who had not had any specific antileprosy therapy, were included in this trial. At entry to trial blood and urine samples should be negative for dapsone and its metabolites, haemoglobin should be more than $8 \mathrm{~g} / 100 \mathrm{ml}$, and the patient should have no other complicating general illness such as tuberculosis, diabetes, renal failure, or malignancy. Those who satisfied the criteria for inclusion were assigned to clofazimine or to dapsone according to a list of random allocation prepared earlier and kept confidential by the pharmacy department. Packages of these two drugs labelled $1,2,3$, etc. were given out when patients were admitted into the series.

For each patient entering the trial the past history, the present complaints, detailed physical examination findings, and laboratory investigation results were entered on a special form. Subsequently, a form was filled in every month during the first three months and once every three months thereafter, indicating the progress of the patient and the findings of physical examination and laboratory investigations.

If the clinical condition deteriorated because of uncontrolled reaction, even when reaction was treated in another trial, the patient was removed from the trial. Further, if the patient developed pulmonary tuberculosis or severe intercurrent infection needing steroids he was removed from the trial.

TABLE I-Duration of Observation in the Two Drug Groups

\begin{tabular}{|c|c|c|c|c|c|c|c|}
\hline \multicolumn{5}{|c|}{ No. of Months Observed } & \multirow{2}{*}{$\begin{array}{c}\text { Clofazimine } \\
1 \\
3 \\
2 \\
3 \\
3 \\
1\end{array}$} & \multirow{2}{*}{$\begin{array}{c}\text { Dapsone } \\
- \\
3 \\
2 \\
3 \\
1 \\
1\end{array}$} & \multirow{2}{*}{$\begin{array}{c}\text { Total } \\
1 \\
6 \\
4 \\
6 \\
4 \\
2\end{array}$} \\
\hline $\begin{array}{c}7-9 \\
10-12 \\
13-15 \\
16-18 \\
19-21 \\
22-24\end{array}$ & $\begin{array}{l}\cdots \\
\cdots \\
\cdots \\
\cdots\end{array}$ & $\begin{array}{l}\cdots \\
\cdots \\
\cdots \\
\cdots\end{array}$ & $\begin{array}{l}\ldots \\
\cdots \\
\cdots \\
\cdots\end{array}$ & $\begin{array}{l}\ldots \\
\cdots \\
\cdots \\
\therefore\end{array}$ & & & \\
\hline & & To & & & 13 & 10 & 23 \\
\hline
\end{tabular}

Twenty-three patients who had been observed for at least six months in this trial are included in this study-13 were on clofazimine and 10 on dapsone. The age distribution of the patients in the two drug groups were similar. The duration of observation is shown in Table I. 


\section{Findings}

The initial morphological index and bacterial index are presented in Table II. The distribution of patients according to severity of disease, as judged by their initial morphological and bacterial indices, was similar in the two drug groups. The changes in the morphological and bacterial indices were computed (Table III). No significant differences could be discerned between the two drug groups in terms of the changes in the morphological and bacterial indices. In three cases given clofazimine and in three given dapsone there was either no change or a slight rise in the morphological and bacterial indices. In general, however, there was a fall in both these indices.

TABLE II-Initial Morphological Index (M.I.) and Bacterial Index (B.I.) at Entry to the Trial

\begin{tabular}{|c|c|c|c|c|c|}
\hline M.I. & Clofazimine & Dapsone & B.I. & Clofazimine & Dapsone \\
\hline $\begin{array}{l}0 \\
0 \cdot 1-0 \cdot 5 \quad \ldots \\
0 \cdot 6-1 \cdot 0 \\
1 \cdot 1-1 \cdot 5 \\
1 \cdot 6-2 \cdot 0 \\
2 \cdot 1 \text { and over }\end{array}$ & $\begin{array}{l}1 \\
2 \\
7 \\
1 \\
1 \\
1\end{array}$ & $\begin{array}{l}\overline{2} \\
5 \\
1 \\
1 \\
1\end{array}$ & $\begin{array}{l}1 \cdot 1-2 \cdot 0 \quad \ldots \\
2 \cdot 1-3 \cdot 0 \quad \ldots \\
3 \cdot 1-4 \cdot 0 \quad \ldots \\
4 \cdot 1 \text { and over }\end{array}$ & $\begin{array}{l}2 \\
2 \\
6 \\
3\end{array}$ & $\begin{array}{l}\overline{2} \\
5 \\
3\end{array}$ \\
\hline Total & 13 & 10 & & 13 & 10 \\
\hline
\end{tabular}

TABLE III-Changes in Morphological and Bacterial Indices in the Two Drug Groups

\begin{tabular}{|c|c|c|c|c|c|}
\hline \multirow{2}{*}{\multicolumn{2}{|c|}{ Change }} & \multicolumn{2}{|c|}{ M.I. } & \multicolumn{2}{|c|}{ B.I. } \\
\hline & & Clofazimine & Dapsone & Clofazimine & Dapsone \\
\hline $\begin{array}{ll}-0.1 \text { to }-0.5 & \text { (rise) } \\
0 & \\
+0.1 \text { to }+0.5 & \text { (fall) } \\
+0.6 \text { to }+1.0 & \text { (fall) } \\
+1.1 \text { to }+2.0 & \text { (fall) } \\
+2.1 \text { to }+2.9 & \text { (fall) }\end{array}$ & $\begin{array}{l}. \\
\ldots \\
\because \\
\therefore\end{array}$ & $\begin{array}{c}\frac{3}{4} \\
4 \\
1 \\
1\end{array}$ & $\begin{array}{l}2 \\
1 \\
1 \\
4 \\
1 \\
1\end{array}$ & $\begin{array}{l}2 \\
1 \\
6 \\
2 \\
1 \\
1\end{array}$ & $\begin{array}{r}- \\
5 \\
3 \\
2 \\
-\end{array}$ \\
\hline Total & . & 13 & 10 & 13 & 10 \\
\hline
\end{tabular}

Three out of 13 patients on clofazimine and two out of 10 on dapsone developed erythema nodosum leprosum. One patient on clofazimine developed necrotizing erythema nodosum leprosum, which cleared up with higher doses of clofazimine. None of the patients had to be removed from the trial because of reaction. There does not seem to be any significant difference in the incidence of erythema nodosum leprosum in the two groups during the follow-up period.

The changes in the skin lesions in the two groups were similar. No dramatic changes were noticed except among those with nodular lesions, in whom striking improvement was found with clofazimine as well as with dapsone.

The changes in neurological status with reference to ulnar, median, radial, lateral, popliteal, and facial nerves are summarized in Table IV. No significant differences were noticed between the two drug groups. One patient given clofazimine showed significant improvement in the motor function (as determined by strength-duration curves) while no change was noticed among the rest of the patients. In terms of sensory function one patient in the dapsone group showed significant deterioration compared with none given clofazimine.

TABLE IV-Changes in Motor and Sensory Functions of the Nerves

\begin{tabular}{|c|c|c|c|c|c|c|c|}
\hline & \multirow{2}{*}{\multicolumn{2}{|c|}{ Change }} & & \multicolumn{2}{|c|}{ Motor Function } & \multicolumn{2}{|c|}{ Sensory Function } \\
\hline & & & & Clofazimine & Dapsone & Clofazimine & Dapsone \\
\hline \multirow[t]{2}{*}{$\begin{array}{l}\text { Improved } \\
\text { Same } \\
\text { Worse }\end{array}$} & $\begin{array}{l}\cdots \\
\cdots\end{array}$ & $\begin{array}{l}\cdots \\
\because\end{array}$ & $\begin{array}{l}. \\
\therefore\end{array}$ & $\begin{array}{r}1 \\
12 \\
\end{array}$ & $\underline{10}$ & $\begin{array}{r}2 \\
11 \\
-\end{array}$ & $\begin{array}{l}2 \\
7 \\
1\end{array}$ \\
\hline & Total & .. & .. & 13 & 10 & 13 & 10 \\
\hline
\end{tabular}

The changes in the haemoglobin concentration, packed cell volume, reticulocyte level, total white cell count, and the erythrocyte sedimentation rate in the first hour were not significant during the period of study and were similar in the two groups (Table V). There was no significant change in renal function, urine analysis, detailed liver function tests, including serum glutamic-pyruvic transaminase (SGPT) and alkaline phosphatase, and in the levels of calcium, phosphorous, sodium, and potassium in the serum as well as in fasting blood sugar values among patients in both the groups (Table V).

TABLE v-Mean Change (Final Value Minus Initial Value) in Specified Characteristics of Patients in the Two Drug Groups

\begin{tabular}{|c|c|c|c|c|}
\hline \multirow{2}{*}{ Change } & \multicolumn{2}{|c|}{ Clofazimine } & \multicolumn{2}{|c|}{ Dapsone } \\
\hline & Mean & S.D. & Mean & S.D. \\
\hline $\begin{array}{ll}\text { Haemoglobin }(\mathrm{g} / 100 \mathrm{ml}) & \ldots \\
\text { P.C.V. (\%) } & \ldots\end{array}$ & $\begin{array}{r}-0 \cdot 7 \\
-2 \cdot 2 \\
-0 \cdot 1 \\
+877 \\
+13.4\end{array}$ & $\begin{array}{c}1 \cdot 6 \\
4 \cdot 9 \\
0 \cdot 4 \\
2,062 \\
30 \cdot 3\end{array}$ & $\begin{array}{r}-0 \cdot 2 \\
-0 \cdot 8 \\
+0 \cdot 0 \\
+922 \\
+1 \cdot 6\end{array}$ & $\begin{array}{r}1 \cdot 7 \\
4 \cdot 9 \\
0 \cdot 3 \\
2,949 \\
31 \cdot 3\end{array}$ \\
\hline $\begin{array}{l}\text { ml) } \\
\text { Serum albumin }(\mathrm{g} / 100 \mathrm{ml}) \\
\text { Serum globulin }(\mathrm{g} / 100 \mathrm{ml}) \\
\text { Icteric index (units) } \\
\text { Thymol turbidity (units) }\end{array}$ & $\begin{array}{l}-0.6 \\
-0.4 \\
-0.2 \\
+0.3 \\
-0.6 \\
-0.5\end{array}$ & $\begin{array}{l}0.5 \\
0.5 \\
0.5 \\
1.5 \\
2.1 \\
7.7\end{array}$ & $\begin{array}{l}+0.1 \\
+0.3 \\
-0.1 \\
+0.3 \\
-0.9 \\
-1.2\end{array}$ & $\begin{array}{r}0.5 \\
0.4 \\
0.6 \\
1.9 \\
2.6 \\
10.9\end{array}$ \\
\hline 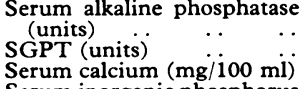 & $\begin{array}{r}+1.2 \\
+10.9 \\
+0.1\end{array}$ & $\begin{array}{r}3 \cdot 6 \\
41 \cdot 1 \\
1 \cdot 1\end{array}$ & $\begin{array}{r}+1 \cdot 8 \\
+26 \cdot 4 \\
-0 \cdot 0\end{array}$ & $\begin{array}{r}2 \cdot 8 \\
31 \cdot 4 \\
0 \cdot 7\end{array}$ \\
\hline$\underset{(\mathrm{mg} / 100 \mathrm{ml})}{\operatorname{Serum} \text { inorganic phosphorus }}$ & +0.6 & 0.7 & -0.4 & 1.4 \\
\hline
\end{tabular}

There was a trend towards weight gain among patients on clofazimine compared with those on dapsone; the latter showed a trend towards reduction of weight. The difference almost reaches statistical significance $(P<0.05)$. The changes in the body weight in the two drug groups are summarized in Table VI.

TABLE VI-Changes in Body Weight

\begin{tabular}{|c|c|c|c|c|c|}
\hline \multicolumn{4}{|c|}{ Change (kg) } & Clofazimine & Dapsone \\
\hline $\begin{array}{r}-2.0 \text { or more } \\
-0.1 \text { to }-1.9 \\
00 \\
+0.1 \text { to }+1.9 \\
+2.0 \text { or more }\end{array}$ & $\begin{array}{l}. \\
\because \\
\therefore\end{array}$ & $\begin{array}{l}. \\
\therefore \\
\therefore\end{array}$ & $\begin{array}{l}. \\
\because \\
\therefore\end{array}$ & $\begin{array}{l}2 \\
3 \\
3 \\
1 \\
4\end{array}$ & $\begin{array}{l}3 \\
3 \\
2 \\
2 \\
\end{array}$ \\
\hline Mean \pm S.D. & . & & . . & $+0.5 \pm 2.2$ & $-1 \cdot 1 \pm 1 \cdot 6$ \\
\hline
\end{tabular}

In all patients given clofazimine red-brown pigmentation appeared within the first three months and continued throughout the period of trial. There were no other side effects. In 6 of the 10 patients given dapsone hyperpigmentation was observed for varying periods throughout the trial and in four there were no side effects.

\section{Comments}

This controlled clinical trial confirms the findings of other workers that clofazimine is an effective antileprosy drug and that its action on Mycobacterium leprae is comparable to that of dapsone, as judged by its effect on morphological index and bacterial index. Under the conditions of this trial the incidence of erythema nodosum leprosum reaction among patients who were on $100 \mathrm{mg}$ of clofazimine daily was similar to that among those on $100 \mathrm{mg}$ of dapsone daily. It is of interest that even the severe (grade $4+$ ) necrotizing lesions of erythema nodosum leprosum that appeared in patients on clofazimine were well controlled when the dose of clofazimine was increased to $300 \mathrm{mg} /$ day.

The rate of regression of skin lesions was comparable in the two groups, the most striking changes occurring in patients with 
gross infiltration, those with nodular lesions, and among those with high bacillary density on skin smears.

The very detailed monthly assessment of haematological, hepatic, renal, neurological, visual, and cardiac functions failed to show any toxic effects from clofazimine during the period of observation, and thus confirmed the previously gained impression that in the acutely ill, debilitated leprosy patient clofazimine can be safely administered with gratifying therapeutic results. However, the red-brown pigmentation of the skin that was seen in all the patients, coupled with reddish brown urine and sweat and a tendency to development of dry scaly skin, was disturbing to the younger and fairer patients.

The study does not show the superiority of clofazimine over dapsone, in the dose used in this trial, in terms of bacterial death and clearance, resolution of skin lesions, and the incidence of erythema nodosum leprosum. While further controlled studies for a longer period are necessary, we suggest that dapsone, which is much cheaper and does not cause significant pigmentation, is preferable to clofazimine in the routine management of untreated lepromatous leprosy. Clofazimine could be reserved for patients who are either sensitive or resistant to dapsone as well as for those who are distressed by recurrent chronic erythema nodosom leprosum or recurrent chronic peripheral neuritis or both.

\section{References}

Brechet, R. (1963). International fournal of Leprosy, 31, 549.

Browne, S. G. (1965). Leprosy Review, 36, 13

Browne, S. G., and Hogerzeil, L. M. (1962). Leprosy Review, 33, 6.

Chang, Y. T. (1962). In Antimicrobiol Agents and Chemotherapy, ed. J. C. Sylvesta, p. 294. Chicago, American Society for Microbiology.

Davey, T. F. (1964). In Leprosy in Theory and Practice, ed. R. G. Cochrane and T. F. Davey, 2nd edn. pp. 115, 400 . Bristol, Wright.

Faget, G. H., et al. (1943). Public Health Reports, 58, 1729.

Karat, A. B. A., Jeevaratnam Anbu, Karat, S., and Rao, P. S. S. (1970) British Medical fournal, $1,198$.

Pettit, J. H. S., Rees, R. J. W., and Ridley, D. S. (1967). International Fournal of Leprosy, 35, 25.

Ridley, D. S. (1964). In Leprosy in Theory and Practice, ed. R. G. Cochrane and T. F. Davey, 2nd edn., p. 620. Bristol, Wright.

Shepard, C. C., and McRae, D. H. (1965). Fournal of Bacteriology, 89, 365 Williams, T. W., et al. (1965). International fournal of Leprosy, 33, 767.

\title{
Coagulation Defects in Hypoxic Full-term Newborn Infants
}

\author{
M. A. CHADD, P. C. ELWOOD, O. P. GRAY, S. M. MUXWORTHY
}

British Medical fournal, 1971, 4, 516-518

\section{Summary}

Blood clotting was examined in 24 consecutive full-term newborn infants with hypoxia and 23 normal control infants. There was evidence of a gross alteration in the clotting process in the hypoxic infants. The degree of disturbance in clotting seemed to be dependent on the severity of the hypoxia, suggesting a causal relationship. The mechanism involved seemed to be intravascular coagulation. The consumption of clotting factors involved led to the appearance of a haemorrhagic diathesis. This effect seemed to be of short duration, suggesting that direct liver damage plays at most a minor part.

Though there was no evidence of damage in the infants who survived, it is possible that intravascular coagulation induced by hypoxia, by leading to deposition of fibrin, may cause damage to vital organs. Further studies will be required to examine this possibility.

\section{Introduction}

Intracranial haemorrhage is a common finding in neonatal deaths of full-term infants. In a small selected series Haller et al. (1956) found an incidence of $9.5 \%$, Gröntoft (1953) an incidence of over $30 \%$, but the British perinatal birth survey (Butler and Bonham, 1963) showed an incidence of $7.6 \%$ for intraventricular haemorrhage and cerebral birth trauma.

\footnotetext{
Department of Child Health, Welsh National School of Medicine, Cardiff Royal Infirmary, Cardiff CF2 1SZ

M. A. CHADD, M.B., B.CH., D.C.H., Research Fellow

O. P. GRAY, F.R.C.P., D.C.H., Professor

S. M. MUXWORTHY, A.I.M.L.T., Research Technician

Epidemiology Unit of the Medical Research Council, Cardiff CF2 3AS P. C. ELWOOD, M.D., D.C.H., Scientific Member
}

Serious intracranial haemorrhage may be due not only to physical trauma but to other adverse factors, such as a poor coagulation state. Wefring (1962) suggested one cause of haemorrhage to be prothrombin complex deficiency, and investigation of preterm infants has confirmed this and shown an association between intracranial haemorrhage and a deficiency of factor II complex (Gray et al., 1968), but the frequency of haemorrhage from this cause is largely unknown. The level of factor II, which is normally low at birth, may be further depressed by hypoxia, but most of the work which has suggested this has been done in preterm infants and there is a lack of information on the role of this mechanism in fullterm infants. That non-traumatic haemorrhage may be, in part, due to coagulation deficiencies other than factor II has been established in the preterm infants (Hathaway et al., 1969) but there are only a few isolated case reports relating to full-term infants (Chessells and Wigglesworth, 1970).

The exact nature of the process by which hypoxia causes haemorrhage is incompletely understood. It has generally been assumed that the process is basically one of direct liver damage, but recent studies (Aballi and de Lamerens, 1962; Hathaway et al., 1969; Berglund, 1970) have indicated that a consumption coagulopathy, usually following disseminated intravascular coagulation, may be a most important mechanism. In view of these areas of doubt we have set out to determine the role of hypoxia in full-term infants as a cause of coagulation disorders. The present study has been undertaken with a comprehensive series of tests over an extended period of time, and the results have been correlated with biochemical and clinical assessments of hypoxia.

\section{Cases and Methods}

Forty-seven full-term infants were studied. These were 24 consecutive hypoxic full-term babies admitted to our unit and 23 full-term control babies who showed no evidence of hypoxia during delivery. These latter were chosen from the nursery, and parental consent for their inclusion was obtained. The Apgar score was estimated by the paediatrician attending 